\title{
MENYEMAI GURU MUHAMMADIYAH BERKEMAJUAN DI SEKOLAH MUHAMMADIYAH ${ }^{1}$
}

\begin{abstract}
Mohamad Ali
Dosen Prodi Pendidikan Agama Islam Fakultas Agama Islam dan Magister Pendidikan Islam Sekolah Pascasarjana Universitas Muhammadiyah Surakarta e-mail:ma122@ums.ac.id

Abstrak: Paska reformasi Mei 1998 virus sekolah unggul menjangkiti pengelola sekolah Muhammadiyah. Bermula dari pengelola SD/MI selanjutnya menular ke tingkat Sekolah Menengah. SD/MI Muhammadiyah unggul telah bermunculan, baik yang di kawasan perkotaan maupun pedesaan. Ia menjadi rujukan utama orang tua siswa dalam mendidik putra-putrinya. Sekolah yang diminati itu adalah sekolah model baru yang mengusung sayap kembar keunggulan, yaitu kemampuan akademisnya kompetitif (intelektual) dan kesalehan beragama (ulama). Ketika sekolah Muhammadiyah model baru ini mampu "merebut kepercayaan masyarakat", pertanyaannya adalah: bagaimana merawat dan memupuk kepercayaan (trust) secara cerdas. Cara paling genial untuk memupuk kepercayaan ialah dengan jalan memperbaiki tata kelola guru. Secara historis, guru Muhammadiyah telah melewati tigazaman, yaitu: guru mubaligh, diikutiguru birokrat, dan saatini tengah memasuki periode transisi untuk menjadi profesional. Tantangan terbesar sekolah Muhammadiyah model baru yang tengah tumbuh ini adalah, bagaimana menjadikan dirinya sebagai rumah yang hangat bagi tumbuh kembang guru Muhammadiyah profesional berkemajuan.
\end{abstract}

Kata kunci: Guru Muhammadiyah, profesionalisme, tata kelola sekolah baru

\section{Pendahuluan}

Geliat dakwah Muhammadiyah yang paling semarak dan fenomenal belakangan ini adalah berkecambahnya Sekolah Dasar/ Madrasah Ibtidiyah (SD/MI) model baru yang disering disebut sebagai "sekolah unggul" atau "sekolah hebat". Gerakan menjadi (becoming) sekolah unggul relatif merata di pelosok Indonesia, terutama yang memiliki basis Muhammadiyah cukup kuat. Bila dibandingkan dengan kawasan-kawasan lain, SD/MI Muhammadiyah di sekitar Solo Raya yang mencakup: kota Solo, Sukoharjo, Klaten, Karanganyar, Sragen, Boyolali dan Wonogiri merupakan kawasan yang sangat subur, paling menggeliat. Ini dapat dilihat dari persebaran sekolah model baru yang mampu menjamah wilayah kecamatan (sub-urban). Dengan simposium sekolah berkemajuan ini diharapkan mampu mengkonsolidasikan dan memperluas radius gerakan sekolah Muhammadiyah model baru (berkemajuan) hingga ke pelosok pedesaan.

Eksistensi sekolah model baru ini dimungkinkan, setidaknya karena didorong tiga faktor. Pertama, gejala mondial berupa pertumbuhan kelas menengah muslim yang menginginkan anak-anaknya menguasai akademis tinggi sekaligus religius. Faktor kedua, basis sosial-finansial-intelektual gerakan Muhammadiyah di kawasan Solo Raya relatif kuat sebagai penopang dan penyulut munculnya sekolah model baru. Faktor ketiga, munculnya kesadaran baru pengelola-penyelenggara pendidikan Muhammadiyah bahwa tanpa inovasi dan improvisasi sekolah Muhammadiyah akan ditinggalkan masyarakat. Jalinan

1 Tulisan ini dikembangkan dari paper penulis yang disampaikan pada Simposiun Sekolah Berkemajuan yang diselenggarakan oleh "Forum Guru Muhammadiyah" SD-MI Muhammadiyah Solo Raya bekerjasama dengan Program Studi PGSD FKIP UMS, tanggal 19 Oktober 2016 di Auditorium Muhammad Jasman Al-Kindi UMS. 
ketiga faktor inilah yang membuat SDMI Muhammadiyah di kawasan ini terlihat begitu dinamis.

Di tengah hingar bingar semarak $\mathrm{SD} /$ MI Muhammadiyah model baru (sekolah unggul) ini, sebuah pertanyaan kecil patut direnungkan: Apakah sekolah-sekolah model baru ini memiliki energi yang cukup untuk terus mengakselerasi dirinya, sehingga bisa menjelma menjadi sekolah Muhammadiyah berkemajuan?. Bila tidak memiliki energi dan strategi tepat, maka kemunculan sekolah model baru ini diprediksi akan menjadi fenomena sesaat, laksana buih yang ringkih diterpa ombak. Namun bila jawabnya positif, maka sekolah model baru itu laksana karang yang kokoh menahan gelombang ombak kehidupun. Gelombang ombak pendidikan bisa dalam bentuk kebijakan-kebijakan pemerintah yang seringkali kontraproduktif, aspirasi/tuntutan masyakat yang terus meningkat, maupun iklim persaingan sekolah yang semakin kompetitif.

Sesungguhnya energi ataupun modal terbesar keberlanjutan suatu sekolah tergantung pada penanganan gurunya. Sudahkah sekolah Muhammadiyah model baru memikirkan tata kelola guru yang mampu menjamin mereka kerasan berkreasi sehingga tumbuh menjadi guru Muhammadiyah berkemajuan?. Sudahkan sekolah-sekolah model baru ini menjadi rumah yang ramah untuk bersemainya guru Muhammadiyah berkemajuan? Masalah ini harus dijadikan prioritas utama dalam agenda sekolah baru. Dan, tulisan ringkas ini berupaya turut urun rembug dengan menjajaginya secara sepintas, sehingga bisa membuka berbagai kemungkinan dan peta jalan menuju terbangunnya guru Muhammadiyah berkemajuan.

Perbincangan tentang tata kelola guru Muhammmadiyah sudah menjadi isu nasional. Pada Rapat Kerja Nasional (Rakernas) Majelis Dikdasmen PP Muhammadiyah periode 2015-2020 berlangsung 12-14 Mei 2016 di Yogyakarta mengusung tema perbaikan tata kelola pendidikan Muhammadiyah. Ini sejalan dengan program kerja Majelis Dikdasmen, yang mengusung visi: "Berkembangnya fungsi pendidikan dasar dan menengah Muhammadiyah mencakup sekolah, madrasah dan pesantren yang berbasis Al-Islam Kemuhammadiyahan, holistik integratif, bertata kelola baik, berdaya saing dan berkeunggulan"2.

Salah satu produk Rakernas yang penting diperbincangkan lebih mendalam yaitu munculnya prakarsa pembentukan Forum Guru Muhammadiyah (FGM) dan mendaulat Pahri Kepala Sekolah SMK Muhammadiyah Gondanglegi Malang sebagai ketua. Saat ini FGM sudah terbentuk kepengurusan sampai tingkat kabupaten/kota. Kehadiran FGM bertujuan untuk memantapkan jati diri dan memupuk semangat guru Muhammadiyah menjadi guru profesional dan mencerdaskan (SM No. 11/1-15 Juni 2016, h.59). FGM merupakan satu satunya organisasi profesi guru Muhammadiyah yang diakui secara sah oleh Majelis Dikdasmen PP Muhammadiyah.

Kehadiran FGM sebagai organisasi profesi guru Muhammadiyah mencerminkan tumbuhnya kesadaran baru dikalangan pengelola dan penyelangga pendidikan Muhammadiyah. Yaitu kesadaran bahwa untuk menjadi sekolah yang berkualifikasi unggul, atau minimal sekolah bertipe premium, harus memperbaiki tata kelola guru-gurunya. Pada saat bersamaan guruguru Muhammadiyah juga menyadari untuk meningkatkan profesionalisme hanya bisa dilakukan dengan jalan kolaborasi dan saling belajar dengan guru-guru maupun sekolah Muhammadiyah yang lain. Dengan terbentuknya FGM, maka dengan sendirinya di lembaga pendidikan Muhammadiyah hanya ada satu organisasi profesi guru yang diakui, yaitu FGM.

Tumbuhnya kesadaran untuk memperbaiki tata kelola sekolah dan

\footnotetext{
2 Penulis menjadi salah satu partisipan dan sekaligus menjadi salah satu narasumber yang membahas revitaliasi AlIslam dan Kemuhammadiyahan bersama Dr. Tasman Hamami dari IAIN Sunan Kalijaga, sekaligus wakil ketua Majelis Dikdasmen PP Muhammadiyah.
} 
meningkatan profesionalisme guru beriringan dengan perubahan kebijakan Majelis Dikdasmen PP Muhammadiyah. Majelis Dikdasmen telah dan masing terus menyusun peraturan-peraturan yang dapat dijadikan panduan oleh sekolah Muhammadiyah dalam memperbaiki tata kelola; mulai dari pengaturan tata kelola keuangan, kepegawaian, maupun penyelenggaran pembelajaran Al-Islam dan Kemuhammadiyahan.

Berbagai prakarsa baru baik ditingkat pengelola dan guru, maupun penyelanggara (baca: majelis Dikdasmen), ini sungguh penting, karena mencerminkan pergeseran kesadaran dari "guru birokrat" menjadi "guru profesional". Bila menengok jauh ke belakang, jati diri guru-guru Muhammadiyah awal bisa disebut "guru mubaligh". Dengan demikian, dari optik sosio-historis guru Muhammadiyah merupakan sebuah potret yang terus berubah, sesuai dengan tantangan zaman dan panggilan sejarah.

Selanjutnya, dibahas secara berturutturut hal-hal sebagai berikut: perjalanan sejarah guru Muhammadiyah, menuju guru Muhammadiyah berkemajuan, dan gambaran sekolah yang mampu menyemai guru berkemajuan.

\section{Pembahasan}

\section{Perjalanan Sejarah Guru Muhammadiyah}

Secara sederhana, saya membagi perjalanan guru Muhammadiyah menjadi tiga periode, yaitu zaman guru sekaligus menjadi seorang mubaligh, zaman guru sekaligus menjadi seorang birokrat, dan zaman guru sekaligus menjadi seorang profesional. Periodesasi ini dibuat berdasarkan sosiologi ilmu pengetahuan, yaitu melihat bentukbentuk kesadaran guru Muhammadiyah dalam suatu masa. Kerangka referensi ini, dengan sedikit modifikasi, penulis pinjam dari sejarawan UGM yang juga aktivis Muhammadiyah, Kuntowijoyo terkait dengan tahap-tahap atau periodesasi kesadaran umat. Kuntowijoyo secara garis besar membagi tahapan kesadaran umat Islam menjadi tiga, yaitu periode mitis, ideologis, dan idea/keilmuan ${ }^{3}$.

Sebagaimana disinggung di muka, wajah atau potret guru Muhammadiyah mengalami perubahan. Bermulai dari guru mubaligh, berubah menjadi guru birokrat, dan guru profesional. Dilihat dari rentang waktu, kemunculan guru mubaligh bersamaan dengan berdirinya persyarikatan Muhammadiyah. Perluasan wilayah gerak dakwah Muhammadiyah pada periode awal karena ditopang oleh guru mubaligh ini. Ketua PP Muhammadiyah terlama, A.R. Fakhruddin (1985: 20-25) menyebut mereka sebagai "anak panah" Muhammadiyah. Hamka, Yunus Anies, M. Bazar Makruf, Raden Himam, untuk menyebut beberapa nama yang cukup dikenal publik.

Sebagian besar dari mereka adalah keluaran Mualimin dan tabligh school Yogyakarta yang dikirim ke hampir seluruh wilayah Indonesia atas permintaan Muhammadiyah setempat. Guru mubaligh adalah pioner yang melakukan babad alas dakwah Muhammadiyah di seluruh penjuru Tanah Air. Mereka berbaur dengan masyarakat setempat, dan memandunya dalam merintis pengajian, mendirikan sekolah, turut mendirikan masjid/mushola baru dan lain-lain. Singkatnya, mereka menjadi penggerak dakwah secara total, menjadi guru di lembaga pendidikan Muhammadiyah pada siang hari, dan selebihnya ia berperan sebagai mubaligh yang mencerahkan publik.

Sumber penghidupan guru mubaligh berasal dari iuran tokoh-tokoh Muhammadiyah setempat, yang umumnya adalah pedagang (seorang saudagar) sehingga tidak keberatan untuk menyisihkan uang untuk dakwah. Saat itu, guru mubaligh dipandang sebagai lapisan elit oleh masyarakat. Oleh sebab itu, tidak sedikit dari mereka yang kemudian menikah dengan wanita setempat sehingga malah tinggal di tepat itu selamanya. Konon, ayah Mufidah Jusuf Kalla tergolong guru mubaligh tipe ini.

\footnotetext{
3 Kuntowijoyo. 1994. Dinamika Sejarah Umat Islam Indoensia. Yogyakarta: Salahuddin Press, hlm. 29-39.
} 
Potret guru mubaligh berangsur memudar, dan sekitar tahun 1970-an sketsa guru birokrat mulai tergambar. Jargon "pembangunan" Orde Baru yang menjadikan ekonomi sebagai panglima dengan jalan menggenjot pertumbuhan, secara otomatis memerlukan tenaga kerja terdidik sehingga perluasan akses pendidikan menjadi niscaya. Lembaga pendidikan Muhammadiyah yang telah dirintis oleh guru mubaligh, kemudian banyak diisi oleh guru-guru birokrat. Guru birokrat adalah guru-guru PNS yang digaji oleh pemerintah, tetapi bekerja di sekolah Muhammadiyah. Pun, ketika purna tugas mereka masih menerima uang pensiun. Karena orde baru mengembangkan ideologi monoloyalitas (loyalitas tunggal), yaitu hanya loyal kepada pemerintah dan Golkar, maka hanya sedikit dari mereka yang berani keluar dari pakem loyalitas tunggal alias monoloyalitas.

Secara finansial, guru birokrat menguntungkan Muhammadiyah. Karena tidak perlu mengeluarkan uang untuk menggajinya, Negara yang menggaji. Namun, belakangan disadari bahwa tidak sedikit dari guru birokrat dalam mengelola dan memperlakukan sekolah Muhammadiyah seperti halnya sekolah negeri. Akibatnya, secara real di kancah sungguh sulit membedakan pola manajemen maupun budaya sekolah Muhammadiyah dengan sekolah negeri.

Sinar guru birokrat meredup seiring runtuhnya pemerintahan Orde Baru 1998. Sebab, kata kunci guru birokrat adalah pemerintah. Kala peran kesejarahan guru birokrat berakhir, secara pelan tapi pasti mulai tumbuh kesadaran guru profesional. Secara formal ditandai dengan lahirnya UU No. 14 tahun 2005 tentang guru dan dosen sebagai bentuk pengakuan Negara bahwa guru (dosen) adalah pekerjaan profesional.

Menurut undang-undang tersebut, profesionalisme adalah pekerjaan atau kegiatan yang dilakukan oleh sesorang dan menjadi sumber penghasilan kehidupan yang memerlukan keahlian, kemahiran, atau kecakapan yang memenuhi standar mutu atau norma tertentu serta memerlukan pendidikan profesi ${ }^{4}$. Kaum profesional, kata Daryl Koehn ${ }^{5}$, adalah mereka yang memiliki dan melaksanakan otoritas sah di mata mereka dan klien sesuai dengan janjijanji besarnya untuk melayani kebaikan/ kepentingan khusus. Frans Magnis Suseno ${ }^{6}$ memahami profesionalisme sebagai sikap dan kemampuan yang erat sekali hubungannya dengan seluruh kepribadian kita. Kata kunci kaum profesional adalah berkepribadian dan melayani kebaikan publik/masyarakat . Kata kunci ini berbeda secara diametral dengan guru birokrat yang kata kuncinya ialah pemerintah.

Dengan demikian, guru Muhammadiyah profesional mengutamakan pelayanan prima dan memastikan bahwa setiap siswa dan stakeholder puas. Ujian utama guru profesional ialah kepuasan pelanggan (siswa-stakeholder). Semakin prima layanan, samakin tinggi kepercayaan (trust) publik, yang dikonversi dalam bentuk kerelaan mereka untuk mengeluarkan biaya sesuai kebutuhan sekolah. Biaya operasional sekolah, termasuk gaji guru, sebagian besar berasal dari publik/masyarakat. Eksistensi sekolah (madrasah/pesantren/perguruan tinggi) Muhammadiyah bergantung pada kualitas layanan dan prestasi yang ditorehkan. Secara ringkas, perjalanan sejarah guru Muhammadiyah dapat dilihat pada tabel 1 berikut ini.

4 Undang-undang No. 14 Tahun 2005 tentang Guru dan Dosen

5 Daryl Koehn. 2000. Landasan Etika Profesi. Terj. Agus M. Hardjana. Yogyakarta: Kanisius, hlm. 13.

6 Frans Magnis-Suseno. 1999. Berfilsafat dari Konteks. Jakarta: Gramedia, hlm. 148.

34 I ishraqi, Volume 1 No. 1 Januari 2017 ... (31-39) 
Tabel 1. Perjalanan Sejarah Guru Muhammadiyah

\begin{tabular}{llll}
\hline \multicolumn{1}{c}{ Periodesasi } & Sumber Penghidupan & \multicolumn{1}{c}{ Orientasi Kerja } & Tantangan Zaman \\
\hline $\begin{array}{l}\text { Guru Mubaligh } \\
(1912-1960)\end{array}$ & $\begin{array}{l}\text { Saudagar } \\
\text { Muhammadiyah }\end{array}$ & $\begin{array}{l}\text { Menggerakan dakwah } \\
\text { dan merintis gerakan } \\
\text { Muhammadiyah }\end{array}$ & Pergolakan sosial-politik \\
Guru Birokrat & Pemerintah/Negara & $\begin{array}{l}\text { Monoloyalitas, } \\
\text { birokratis (PNS) }\end{array}$ & Ideologi pembangunan Orde \\
$(1970-2000)$ & & Layanan prima kepada & Keterbukaan, kontestasi \& \\
Guru Profesional & Sekolah & pelanggan untuk & konsolidasi demokrasi \\
\hline
\end{tabular}

Sumber: Diolah dari penjelasan perjalanan historis guru Muhammadiyah

Dari tabel di atas dapat diketahui bahwa tuntutan sejarah dan semangat zaman guru Muhammadiyah masa kini adalah menjadi seorang guru Muhammadiyah profesional. Sayangnya kesadaran ini belum merata. Sebagian besar dari kita masih terbenam dalam alam pikiran guru birokrat. Oleh sebab itu, meski masih bersifat embrional, tetapi kehadiran guru profesional amat penting. Karena ia berada di garda paling depan yang mewakili kesadaran kolektif, respons, kesaksian dari sebuah generasi peralihan. Guru-guru Muhammadiyah yang kini telah menyadari tugas kesejarahannya sebagai guru profesional merupakan pioner sekaligus penarik gerbang kemajuan pendidikan Muhammadiyah.

Konsekuensi dari peralihan guru birokrat ke guru profesional adalah pembenahan tata kelola sekolah dan majelis Dikdasmen secara menyeluruh. Penghargaan tinggi layak diberikan pada guru-guru Muhammadiyah profesional. Cara yang paling tepat untuk menghargai mereka adalah dengan jalan merancang-bangun tata kelola sekolah yang mampu menjamin kebebasan dan kreatifitasnya, memberi gaji secara layak, dan tentu saja memikirkan dana pensiun agar bisa menikmati hari tua dengan penuh kegembiraan ${ }^{7}$.

Ini artinya, tugas Dikdasmen dan kepala sekolah sangat berat. Harus fokus dan mencurahkan segenap tenaga, pikiran, dan finansial untuk memberbaiki tata kelola tenaga pendidikan maupun keuangan institusi pendidikan Muhammadiyah.

\section{Menuju Guru Muhammadiyah Profesional Berkemajuan}

Mantan Ketua PWM Jawa Tengah, Sahlan Rosyidi ${ }^{8}$ dalam bukunya yang berjudul Kemuhammadiyahan mendefinisikan guru Muhammadiyah sebagai seseorang yang mengajar pada sekolah Muhammadiyah, baik guru-guru PNS maupun yang diangkat oleh persyarikatan. Definisi yang diajukan Sahlan Rosyidi ini secara umum dapat diterima, namun dengan tiga catatan. Pertama, seiring perluasan horisontal pendidikan Muhammadiyah, sehingga tidak hanya mengelola sekolah maupun madrasah, tetapi juga pesantren, di Majelis Dikdasmen PP Muhammadiyah periode ini ada wakil ketua yang mengurusi pesantren. Oleh karena itu, para pendidik di lembaga-lembaga tersebut baik yang disebut kyai ataupun ustadz bisa dicakup ke dalam pengertian guru.

Catatan kedua, lembaga pendidikan Muhammadiyah juga tumbuh secara vertikal, sejak tahun 1950-an mulai berdiri Perguruan Tinggi Muhammadiyah (PTM) dan saat ini telah berdiri 177 PTM. Secara formal pendidik di perguruan tinggi disebut dosen, namun dalam tulisan ini pengertian guru juga mencakup dosen. Logikanya sederhana, dosen yang berhasil mencapai profesor disebut guru besar, bukan dosen besar. Catatan terakhir, guru Muhammadiyah

7 Mohamad Ali. 2016. "Guru Muhammadiyah: Potret yang Berubah”, dalam Suara Muhammadiyah No. 23 Tahun Ke101/1-15 Desember, hlm. 28-29.

8 Sahlan Rosyidi. 1990. Kemuhammadiyahan. Surakarta: UMS Press, hlm. 49-122. 
adalah semua pendidik yang mengajar di lembaga pendidikan Muhammadiyah, baik itu guru PNS yang diperbantukan (DPK), guru tetap persyarikatan, guru kontrak persyarikatan maupun guru tidak tetap.

Sementara itu, menurut draf ketentuan pengelolaan kepegawaian Majelis Dikdasmen PP Muhammadiyah, guru Muhammadiyah adalah pendidik profesional yang berkepribadian Muhammadiyah dengan tugas utama mendidik, mengajar, membimbing, mengarahkan, melatih, menilai, dan mengevaluasi peserta didik. Definisi ini beririsan dengan pengertian guru sebagaimana tercantum dalam UU No.14 Tahun 2005 tentang guru dan dosen. Hanya saja dalam draft ketentuan kepegawaian Majelis Dikdasmen menekankan pada berkepribadian Muhammadiyah. Kata kunci berkepribadian Muhammadiyah inilah yang membedakan sekaligus menjadi ciri khas guru Muhammadiyah bila disandingkan dengan profesi guru pada umumnya.

Pribadi ialah individu yang berbudi dan berkehendak. Berkepribadian berarti dasar keseluruhan dan kesatuan tindakan manusia yang berbudi dan berkehendak itu. Yang dimaksud berkepribadian Muhammadiyah adalah terinternalisasi dan mempribadinya keseluruhan nilai-nilai maupun pandangan hidup Muhammadiyah sebagaimana tercermin dari produk-produk persyarikatan seperti Matan Keyakinan dan Cita Cita Hidup Muhammadiay $(\mathrm{MKCH})$, Pedoman Hidup Islami Warga Muhammadiyah (PHIWM) dan lain-lain sehingga itu dijadikan dasar tindakan guru-guru Muhammadiyah. Ringkasnya, berkepribadian Muhammadiyah menjadikan pemahaman dan nilai-nilai muhammadiyah di dalam bertindak.

Masih menyitir pendapat Sahlan Rosyidi, sikap mental atau kepribadian yang harus melekat dan menjadi nafas bagi seorang guru Muhammadiyah dalam menjalani kehidupan dan keprofesiannya adalah: (1) siap menjalani perintah Allah SWT, (2) jiwa pengabdian, (3) ikhlas beramal, (4) memusatkan segala sesuatu hanya kepada Allah SWT, (5) sholat secara aktif (berjamaah), dan (6) keyakinan akan kelurusan/kebenaran agama Islam. Secara religius identifikasi di atas sudah tepat.

Bila identifikasi profesionalitas guru dan kepribadian Muhammadiyah disinergikan lahirlah pokok-pokok pikiran kode etik guru Muhammadiyah. Berikut saya kutipkan secara utuh kode etik guru Muhammadiyah sebagaimana tertuang dalam draf ketentuan kepegawaian Majelis Dikdasmen PP Muhammadiyah:

a. Berkepribadian Muhammadiyah;

b. Mentaati peraturan yang berlaku di persyarikatan dan kedinasan;

c. Menjaga nama baik persyarikatan;

d. Berpartisipasi aktif dalam kegiatan persyarikatan;

e. Melaksanakan tugas dengan penuh tanggungjawab;

f. Bekerja dengan jujur, tertib, cermat, dan bersemangat;

g. Mentaati jam kerja;

h. Menciptakan suasana kerja yang harmonis dan kondusif;

i. Melaporkan kepada atasan, apabila ada hal yang merugikan persyarikatan;

j. Menggunakan asset Muhammadiyah secara bertanggunjawab;

k. Memberikan pelayanan sebaikbaiknya sesuai tugas masingmasing;

1. Bersikap tegas, adil, dan bijaksana;

m. Membimbing bawahan dalam melaksanakan tugas;

n. Menjadi suri teladan;

o. Meningkatkan prestasi dan karir;

p. Mentaati ketentuan peraturan perundang-undangan yang berlaku;

q. Berpakaian rapi dan sopan, serta bersikap dan bertingkahlaku santun;

r. Menciptakan kawasan tanpa rokok di lingkungan satuan pendidikan.

Dari 18 kode etik guru Muhammadiyah masih ada hal yang kurang eksplisit, misalnya perlu ditambahkan sikap mental seorang guru profesional, seperti sikap lapang dada untuk berdialog dan terus mencari kebenaran 
dan selalu berusaha untuk meningkatkan kapasitas diri secara berkelanjutan dengan cara menjadi pembelajar sepanjang hayat. Bersedia berhenti mengajar ketika sudah tidak sempat membaca dan belajar.

Berdasarkan alur uraian di atas dapat digarisbawahi di sini bahwa guru Muhammadiyah adalah guru profesional plus berkepribadian Muhammadiyah. Sedangkan identikasi berkemajuan di belakang konsep guru Muhammadiyah untuk menunjukkan cita ideal seorang guru Muhammadiyah yang mestinya memiliki semangat belajar sepanjang hayat dan terlibat aktif untuk memecahkan permasalahan-permasalahan pendidikan maupun kehidupan pada umumnya. Ciri paling nyata dari sosok gutu Muhammadiyah berkemajuan ialah kehadirannya menggembirakan warga sekolah dan mampu memajukan diri dan sekolahnya.

\section{Sekolah Penyemai Guru Berkemajuan}

Bertitik tolak dari tinjuan historis perjalanan guru Muhammadiyah dapat diketahui bahwa pergeseran dari guru birokrat ke guru profesional merupakan keniscayaan sejarah dan secara empirik telah dan terus berlangsung di kancah. Fenomena ini secara kasat mata dapat dilihat dari dekat dengan mengamati guru-guru yang mengajar di SD/MI Muhammadiyah. Sedikit sekali di antara mereka yang berstatus PNS (baca: guru birokrat). Memang masih ada 1 atau 2 guru yang berada di SD/MI Muhammadiyah, tapi rata-rata umurnya sudah di atas 50an tahun. Dalam tempo singkat guru-guru birokrat segera habis dan diganti oleh guru profesional.

Ketika realitas sosial guru-guru Muhammadiyah sudah demikian. Apa langkah yang perlu dilakukan sekolah? Ketika masih aktif mengajar, masih dalam usia produktif, mereka mendedikasikan umur dan tenaganya untuk membesarkan sekolah. Dan, sekolah mampu memberi honor secukupnya atau sesuai kemampuan sekolah sehingga kehidupan seolah berjalan normal. Namun tatkala mereka pensiun, tenaganya tak lagi produktif, siapa yang ngopeni? Sementara hubungan dengan sekolah sudah putus. Di sinilah sebenarnya titik krusial yang harus dipikirkan sekolah Muhammadiyah model baru.

Di era guru birokrat, masalah pensiun sudah ditangani oleh Negara melalui dana pensiun. Namun, di era guru profesional yang harus memikirkan adalah sekolah itu sendiri. Dalam draf pengelolaan kepegawaian Muhammadiyah juga belum/tidak menyinggungnya. Besarannya tidak harus sama dengan pemerintah, tapi disesuaikan dengan kemampuan sekolah. Secara religius, konsep pensiun bisa diturunkan dari konsep amal jariyah, amal yang tidak pernah putus alias berkelanjutan. Bersediakah sekolah Muhammadiyah model baru mengagendakan dan memikirkan serius masalah ini?

Sekolah yang bersedia dan mampu mengagendakan masalah pensiun saya golongkan menjadi sekolah yang subur untuk persemaian guru-guru Muhammadiyah yang berkemajuan. Guru-guru Muhammadiyah berkemajuan inilah yang menjadi asset/ modal utama bagi kemajuan sekolah. Ciri paling menonjol dari sekolah maju adalah terjadinya kapitalisasi (penumpukkan) guru-guru hebat yang mendedikasikan kemampuannya untuk mencerdaskan anak dan memajukan sekolahnya. Sebaliknya, di sekolah terbelakang kebanyakan berisi guruguru yang terpaksa mengajar sambil terus meratapi nasibnya sendiri dan sekolahnya tanpa jalan keluar.

Di pundak para pengelola, sekolah Muhammadiyah model baru ini dipertaruhkan. Tanggung jawab besar dipikul pengelola sekolah Muhammadiyah, sanggupkah mereka memikul tanggung jawab besar ini? Kalau jawabnya, ya. Berikut ini tips atau resep mewujudkan sekolah Muhammadiyah berkemajuan yang ramah untuk tumbuh kembang guru berkemajuan.

Memposisikan sekolah sebagai episentrum (pusat) inovasi/perubahan. Pernyataan ini mengandung arti bahwa perubahan atau inovasi yang dilakukan berdasarkan kebutuhan sekolah, bukan 
sekedar keinginan kepala sekolah ataupun karena desakan dari luar/hanya menuruti kebijakan pemerintah, misalnya. Ini bukan berarti menolak setiap kebijakan dari luar. Inovasi ataupun kebijakan dari luar (pemerintah maupun Muhammadiyah) harus dicerna dan dipahami dengan benar, setelah benar-benar dipahami ternyata bertentangan dengan habitus sekolah, maka harus ditafsirakan sedemikian rupa agar tidak mengganggu iklim sekolah. Namun sebaliknya, bila iklim sekolah perlu ada perbaikan, maka tidak segan-segan untuk diambil langkah-langkah pembenahan agar iklim sekolah mampu mengakselerasi perubahan.

Perubahan "gaya kepemimpinan" dari birokratke enterpreuner. Gayakepemimpinan birokratis yang memposisikan dirinya secara hirarkis seperti penguasa dan selalu berorientasi pada kekuasaan di atasnya. Ini jelas tidak relevan dengan kepemimpinan sekolah Muhammadiyah model baru. Gaya enterpreuner jelas lebih tepat. Sebab melalui gaya entrepreneur kepala sekolah menempatkan diri secara fungsional dalam seluruh gerak sekolah, memandang dan memposisikan guru ataupun tenaga kependidikan yang lain sebagai teman kerja yang egaliter, akrab dan dialogis 9 . Lebih suka mendengar apapun yang menjadi ideaidea guru, bukan hanya memerintah dan main tuding sana sini.

Perubahan orientasi sekolah subsistence (kemelaratan) ke sekolah prosperity

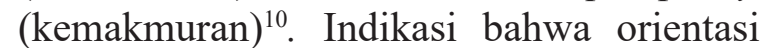
subsistence masih kuat menyelimuti sekolah Muhammadiyah adalah penggunaan anggaran berimbang dimana "pemasukan" dan "pengeluaran" bersaldo 0 (nol). Bila ada sedikit sisa itu dianggap bonus yang bisa digunakan sesukanya, misalnya: jalanjalan yang tidak relevan dengan peningkatan kompetensi guru, beli mobil yang belum tentu sesuai kebutuhan sekolah. Lebih parah lagi ini: bila akan terjadi pergantian Kepala Sekolah seluruh uang sisa (saldo/investasi) dibuat bancakan dibagi-bagi. Orientasi inilah yang membuat sekolah Muhammadiyah melarat-miskin, meskipun muridnya banyak dan gedung menjulang tinggi, tapi tidak memiliki asset. Cara ini harus segera diakhiri dang anti dengan orientasi berkemakmuran. Pola anggaran seimbang-fleksibel-dinamis layak dipertimbangkan. Kalau sekolah ingin maju secara berkelanjutan, setiap tahun harus ada uang yang diinvestasi/diajadikan asset. Sebaiknya pengeluaran sekolah dibagi 3 (tiga), yaitu: operasional sekolah, pembangunan fisik, dan investasi. Bila pola ini bisa diterapkan, maka dana pensiun bisa dialokasikan dari dana asset/investasi tadi.

Menjadikan sekolah sebagai komunitas belajar (learning community). Membaca dan diskusi/dialog harus menjadi budaya warga sekolah. Ketika perubahan berlangsung sedemikian cepat seperti hari ini, semua orang butuh belajar, butuh meningkatkan kapasitas dirinya. Tidak ada yang tetap di dunia ini, kecuali perubahan itu sendiri. Oleh karena itu, jangan sampai terjadi permasalahan yang telah berkembang sedemikian kompleks, tapi cara mengatasinya masih memakai caracara lama. Orang-orang yang demikian ini, umumnya karena tidak mau belajar.

Demikinlah tips, resep ataupun strategi untuk menjadi sekolah Muhammadiyah berkemajuan yang ramah untuk persemaian guru-guru berkemajuan. Tentu bukan perkara mudah untuk mengubah "situasi sekolah saat ini" menuju "cita ideal sekolah berkemajuan". Meski demikian harus ada

\footnotetext{
9 Tony Bush. 2008. Leadhership and Management Development. California: Sage, hlm. 1-15.

10 Kedua konsep itu saya pinjam dari Brubacher, hanya saja saya perluas maknanya dan konteksnya dipertajam pada tingkat kelembagaan-sekolah (mikro). Jadi konsep miskin-makmur(subsistence-prosperity) bukan sekedar konsep ekonomi, tapi mencakup keseluruhan unsur-unsur yang ada di sekolah. Misalnya, sekolah yang baik karena ditopang atau ada penumpukkan guru-guru profesional. Hal ini seiring dengan perluasan makna modal yang tidak hanya terdiri atas uang dan tanah, tapi juga manusia. Di samping itu, Brubacher memahaminya pertautan ekonomi dan pendidikan dalam konteks makro, disini konsep itu saya gunakan untuk menganalisis dimensi mikro-persekolahan. Untuk memahami lebih jauh, lihat John S. Brubacher. 1978. Modern Philosophies of Education. New York: McGraw-Hill Book Company, hlm. 28-31.
} 
yang mengambil prakarsa untuk melakukan perubahan. Orang-orang inilah yang akan dicatat dengan tintas emas dalam mata rantai sejarah suatu sekolah Muhammadiyah. Bila kebetulan sudah ada yang memulai kita dapat melanjutkan dan mengembangkannya lebih jauh.

Transformasi menuju ke arah sekolah Muhammadiyah berkemajuan adalah tugas antara generasi yang memerlukan waktu lama. Alangkah gembiranya bila (generasi) kita menjadi salah satu mata rantai dari sekian banyak generasi yang terus mengembangkan sekolah Muhammadiyah. Bukan malah sebaliknya, menjadi penghancur dan pembunuh sekolah Muhammadiyah.

\section{Kesimpulan}

Dari seluruh uraian di atas dapat ditarik sejumlah benang merah yang menjadi simpulsimpul pemikiran artikel ini. Pertama, kehadiran sekolah Muhammadiyah model baru di berbagai sudut kota, bahkan sudah menjamah sub-urban (kecamatan), patut disukuri. Wujud rasa sukurnya adalah dengan terus bekerja keras membenahi tata kelola sekolah. Kedua, kunci kemajuan pendidikan (sekolah) adalah guru. Dari teropong sejarah, guru Muhammadiyah merupakan potret yang berubah; mulai dari guru mubaligh, guru birokrat, dan guru profesional. Paska reformasi 1998, guru Muhammadiyah menapaki periode guru professional yang dituntut memberikan layanan prima kepada pelanggan. Dengan jalan itu, kepercayaan masyarakat kepada sekolah meningkat tajam yang pada urutannya eksistensi sekolah Muhammadiyah di tengah masyarakat sangat kokoh.

Ketiga, masa depan sekolah model baru sangat ditentukan oleh kemampuan sekolah dalam membangun tata kelola yang baik sehingga guru-guru profesional yang berintegritas intelektual-moral-religius (baca: guru Muhammadiyah berkemajuan) kerasan untuk mendedikasikan dirinya. Sekolah penyemai guru berkemajuan bercirikan: sekolah itu episentrum perubahan, berorientasi prosperity, kepemimpinan kepala sekolah bergaya entrepreneur, dan menjadikan warga sekolah sebagai komunitas pembelajar sepanjang hayat.

\section{Daftar Pustaka}

Ali, Mohamad. "Guru Muhammadiyah: Potret yang Berubah", dalam Suara Muhammadiyah No. 23 Tahun Ke-101/1-15 Desember 2016.

Brubacher, John S. Modern Philosophies of Education. New York: McGraw-Hill Book Company, 1978.

Bush, Tony. Leadhership and Management Development. California: Sage, 2008.

Koehn, Daryl. Landasan Etika Profesi. Terj. Agus M. Hardjana. Yogyakarta: Kanisius, 2000.

Kuntowijoyo. Dinamika Sejarah Umat Islam Indonesia. Yogyakarta: Pustaka Pelajar, 1994.

Majelis Dikdasmen PP Muhammadiyah. Draft Pengelolaan Kepegawaian pada Sekolah Madrasah dan Pondok Pesantren di Lingkungan Pendidikan Dasar dan Menengah Muhammadiyah. Jakarta: PP Muhammadiyah, 2016.

Magnis-Suseno, Frans. Berfilsafat dari Konteks. Jakarta: Gramedia, 1999.

Rosyidi, Sahlan. Kemuhammadiyahan. Surakarta: UMS Press, 1990. 